

\title{
The Experience of Teen Smokers: The Emotions of Teenagers Involved and Emotional Reactions of Parents and Community
}

Siti Marziah Zakaria, Kamalia Kamisan \& Aizan Sofia Amin

To Link this Article: http://dx.doi.org/10.6007/IJARPED/v10-i2/8999

DOI:10.6007/IJARPED/v10-i2/8999

Received: 13 February 2021, Revised: 15 March 2021, Accepted: 31 March 2021

Published Online: 22 April 2021

In-Text Citation: (Zakaria et al., 2021)

To Cite this Article: Zakaria, S. M., Kamisan, K., \& Amin, A. S. (2021). The Experience of Teen Smokers: The Emotions of Teenagers Involved and Emotional Reactions of Parents and Community. International Journal of Academic Research in Business and Social Sciences, 10(2), 109-119.

Copyright: (C) 2021 The Author(s)

Published by Human Resource Management Academic Research Society (www.hrmars.com)

This article is published under the Creative Commons Attribution (CC BY 4.0) license. Anyone may reproduce, distribute, translate and create derivative works of this article (for both commercial and non-commercial purposes), subject to full attribution to the original publication and authors. The full terms of this license may be seen

at: http://creativecommons.org/licences/by/4.0/legalcode

Vol. 10(2) 2021, Pg. 109 - 119

http://hrmars.com/index.php/pages/detail/IJARPED

JOURNAL HOMEPAGE

Full Terms \& Conditions of access and use can be found at http://hrmars.com/index.php/pages/detail/publication-ethics 


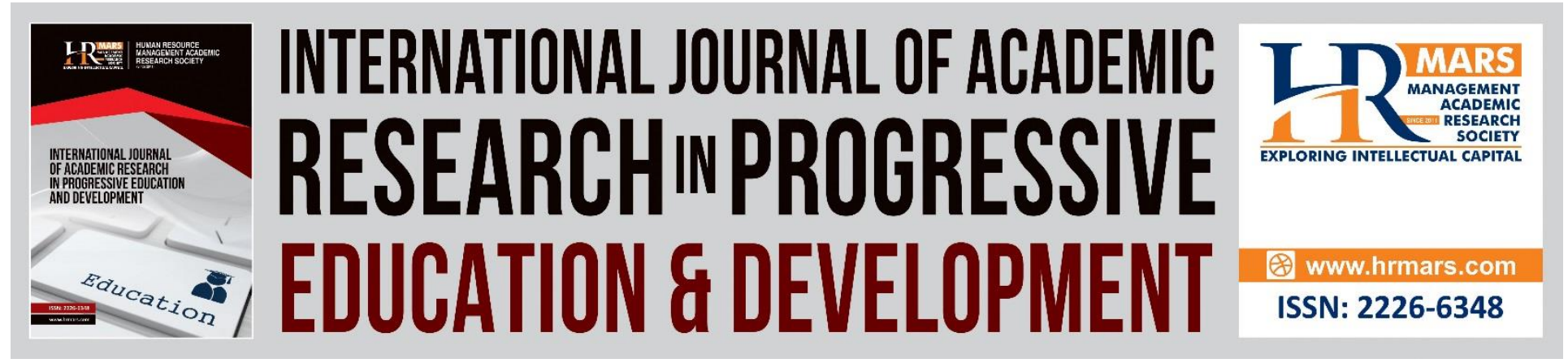

\title{
The Experience of Teen Smokers: The Emotions of Teenagers Involved and Emotional Reactions of Parents and Community
}

\author{
Siti Marziah Zakaria, Kamalia Kamisan \& Aizan Sofia Amin \\ Faculty of Social Sciences and Humanities, National University of Malaysia (UKM) \\ Email:marziah@ukm.edu.my
}

\begin{abstract}
More people are getting addicted to the habit of smoking nowadays and it is getting popular among children and teenagers. Many students from various schools were addicted to smoking and they needed intervention and treatment. Thus, this article will explore the emotions of teenagers after they get involved in smoking. It will also assess the emotional reactions of parents and the community after discovering their behaviour. Exploring these two issues is very important in planning smoking prevention programmes among teenagers and developing relevant psychoeducational modules. The researchers used qualitative method (in-depth interview) to get more detailed and in-depth responses from the participants, namely, teen smokers who are still in school. The researchers selected one of the schools in the state of Johor as the location of the study. Teenagers who have become addicted to smoking would experience a variety of emotions. These emotions are influenced by the reactions of their parents, friends, teachers and surrounding. Negative emotions may occur after they gain awareness of the dangers of smoking from the media and schools. However, many teenagers also feel comfortable with the habit because they feel relieved, less stressed out, and their anxieties faded away after smoking. Thus, the emotions they experience after getting addicted to smoking include (i) positive emotions, (ii) negative emotions, and (iii) neutral emotions. In short, community are supposed to react negatively if young people go astray and take the responsibility to lead them. Teenagers are experiencing an identity crisis that can cause them, if left unattended, to make mistakes in choosing peer groups. Thus, parents need to guide, coach and monitor them to assure positive growth of teenagers.
\end{abstract}

Keywords: Teen Smokers, Emotions, Emotional Reactions, Parents, Community

\section{Introduction}

Malaysian adult males are frequently associated with smoking and that habit is considered normal among them. However, more people are getting addicted to the habit of smoking 
nowadays and it is getting popular among children and teenagers. As stated by the statistics published by Sinar Harian on 15 January 2019, a total of 68,321 secondary school students were identified as smokers through screening conducted by the Ministry of Health in the Oral Healthcare Without Smoking (KOTAK) programme in 2018. According to the former Minister of Health, Datuk Seri Dr. Dzulkefly Ahmad, the number of smokers among secondary school students was equal to 3.7 percent of the total of 1.9 million students screened in the KOTAK 2018 programme.

These statistics have proven that many students from various schools were addicted to smoking and they needed intervention and treatment. Besides, a report on the National Health and Morbidity Survey (NHMS) conducted by the Ministry of Health and published by Berita Harian on 23 November 2019 suggested that smoking has been recorded as the main cause of death. It accounts for about 20,000 deaths every year. That study also showed that 22.8 percent or five million Malaysians aged 15 and above were smokers. Most of them were between 20 to 54 years old, and the majority of them were males.

If this issue is left untreated and does not receive the attention it deserves, Malaysia will probably have a pathetic and visionless young generation. That situation will have a negative impact on the development of the country. According to Mahmood (2001), negative behaviours such as smoking are learned from surrounding factors such as parents, peers, the local community and even the mass media. To address the issue, the Malaysian government has taken several measures to reduce and curb the smoking habit among Malaysians.

A qualitative study was conducted in Malaysia by Yahaya, Akhir and Sulaiman (2018) regarding the causes of smoking among university students. They found that some of the contributing factors were peer influence, stress, personal satisfaction, curiosity and individual perception. A study by Hussin et al. (2004) also stated that peer pressure could influence smoking behaviour. In a peer group, a teenager will be accepted if he or she dares to smoke; otherwise, that teenager will be isolated by peers. This situation compels naive teenagers to be influenced by their friends and get addicted to smoking which eventually becomes a habit that will be difficult for them to control.

This study has proven that smoking is also practised by the younger generation, including those still studying in educational institutions. Various factors cause teenagers to take up smoking. Teenagers and young adults usually spend more time with their peers. Besides spending time together, they also do many things as a group and keep influencing each other to gain acceptance from group members. The smoking habit among teenagers can be attributed to the Social Learning Theory highlighted by Albert Bandura.

For teenagers, conformity in actions and thoughts with the rest of the group members indicate social acceptance by peers. Teenagers are afraid and apprehensive of being ridiculed if their behaviour differs from other group members. To avoid isolation, they gather some courage and risk themselves trying. Due to persistent habits and addiction to nicotine, teenagers 
eventually become hardcore smokers. Other factors that influence teenagers to smoke include the mass media, their idols and their surrounding (The Ministry of Health Malaysia, 2015).

The convenience of buying cigarettes from grocery stores or restaurants has become one reason teenagers find it difficult to quit smoking. Smoking can cause many adverse effects on a person's health and quality of life. According to Tirtosastro and Murdiyati (2010), the level of nicotine found in cigarettes is high; furthermore, it can cause smokers to become addicted and repeat the behaviour until it becomes a habit. Through smoking, a smoker will face health risks; specifically, 30 per cent more likely to get lung cancer, stroke and asthma, and 25 per cent more likely to experience heart disease, cancer and male smokers are more likely to be infertile (The Ministry of Health Malaysia, 2015).

Besides endangering health, another factor rarely observed among teenage smokers is their attitude. They seem to act carelessly and too eager to comply with the majority of the group members; so, they do not realise the bad things that will happen to themselves or those around them. The habit of smoking may be taken lightly nowadays due to many perpetrators; however, the effects of this unnurtured attitude are likely to persist among teenagers and may affect more in the future. They will likely remain to be careless and submissive just for the sake of wanting to get themselves accepted in a group.

The habit of smoking is supposed to bring out guilt among teenagers and make them feel embarrassed by the society that observes them. Negative emotions and reactions from the community are expected to reduce their desire to smoke. Thus, this article will:

- explore the emotions of teenagers after they get involved in smoking.

- assess the emotional reactions of parents and the community after discovering teen's smoking behaviour.

Exploring these two issues is very important in planning smoking prevention programmes among teenagers and developing relevant psychoeducational modules.

\section{Methodology}

In conducting this study, the researchers used the qualitative method to get more detailed and in-depth responses from the participants, namely, teen smokers who are still in school. The researchers selected one of the schools in the state of Johor as the location of the study. To be more specific, the researchers focused on a secondary day school located in the district of Kulai.

The sample of this study consisted of 17-year-old teenagers. They were smokers and went to the school selected by the researchers. In this study, the researchers have obtained nine samples that met the criteria and voluntarily agreed to participate in this study. The technique used by the researchers was a snowball sampling technique because smoking was considered a social problem that usually occurred in groups. Through this technique, the researchers would get as many participants as possible by asking the first sample to introduce other participants who share the same characteristics as him (Mohd Tobi, 2017). 
Vol. 10, No. 2, 2021, E-ISSN: 2226-6348 @ 2021 HRMARS

A series of in-depth interviews have been conducted to get the input from the informants, based on the objectives of the study. A total of 12 semi-structured questions have been used as a protocol or guide for the interview. Durations of the interview were about 1 hour to 2 hours, depending on the informants' input and explanation. The technique employed to analyze the data was thematic analysis. Themes were extracted based on the experiences, views, perceptions and subjective emotions. Validity test has also been conducted to validate and verify the themes extracted from the data. The reseachers have asked the informants and experts to verify the themes.

A total of nine informants were directly involved in this study. All the informants were 17-yearold boys. The informants went to the same school in the state of Johor and settled in the same district. They started smoking at the age of 8 to 15 years old. Most of them live with their parents, except R7 who live with his grandmother. The table below shows demographic information for the nine informants interviewed:

Table 1: Demographic information

\begin{tabular}{ccccccc}
\hline Informant & $\begin{array}{c}\text { Age } \\
\text { (Year) }\end{array}$ & Sex & $\begin{array}{c}\text { Age started } \\
\text { smoking }\end{array}$ & $\begin{array}{c}\text { State of } \\
\text { origin }\end{array}$ & $\begin{array}{c}\text { Number } \\
\text { of } \\
\text { siblings }\end{array}$ & Guardian \\
\hline R1 & 17 & Male & 8 & Johor & 1 & Parents \\
R2 & 17 & Male & 9 & Johor & 3 & Parents \\
R3 & 17 & Male & 13 & Johor & 1 & Parents \\
R4 & 17 & Male & 12 & Johor & 4 & Parents \\
R5 & 17 & Male & 12 & Johor & 5 & Parents \\
R6 & 17 & Male & 13 & Johor & 5 & Parents \\
R7 & 17 & Male & 11 & Johor & 5 & Grandmother \\
R8 & 17 & Male & 11 & Johor & 4 & Parents \\
R9 & 17 & Male & 15 & Johor & 6 & Parents \\
\hline
\end{tabular}

\section{Results and Discussion}

\section{Emotions after Getting Addicted to Smoking}

Teenagers who have become addicted to smoking would experience a variety of emotions. These emotions are influenced by the reactions of their parents, friends, teachers and surrounding. Negative emotions may occur after they gain awareness of the dangers of smoking from the media and schools. However, many teenagers also feel comfortable with the habit because they feel relieved, less stressed out, and their anxieties faded away after smoking. Thus, the emotions they experience after getting addicted to smoking include (i) positive, (ii) negative, and (iii) neutral emotions.

\section{Negative Emotions}

The negative emotions mentioned in this study are specifically referred to as the feeling of regret. Regret is a feeling that describes a person's disapproval of what he or she has done either physically or verbally. The feeling of regretfulness experienced by a hardcore smoker should 
encourage him or her to quit smoking. On the other hand, not all smokers feel the same way as the two teen smokers in this study. Based on the results gathered from these teen smokers, they began to feel regret and guilt for smoking after realising the potential health risks usually experienced by a person who smoked. They also mentioned that smoking could have harmful effects on the lungs. Furthermore, smoking has also caused them to cough a lot. One of the respondents admitted:

Yes, I felt regret. Due to health reasons. Now, I have health problems, sometimes I cough a lot. But to quit is not easy. (R3)

The results of this study are in agreement with a study conducted by Etrawati (2014). She stated that experience has a significant relationship with smoking behaviour or habit. The intended experience is related to what the smoker feels when he or she is smoking cigarettes, whether feeling satisfied, pleasant, and calm or feeling dizzy, nauseous and bitter taste in the mouth. An individual who experiences positive emotions from smoking will be encouraged to resume this behaviour until it becomes a habit and cause that person to be reliant on cigarettes to satisfy the longing for nicotine. On the other hand, smokers who feel differently will be compelled to quit their smoking habit. Regardless, most smokers still smoke due to their excessive addiction to substances in cigarettes; thus, causing them to face difficulties to quit smoking. A teen smoker narrated:

I had once tried to stop smoking, but it was not long. The moment I witnessed my peer smoked, I feel the urge to smoke again. I kept myself busy to forget about smoking, chewing candies to avoid smoking. But it was not working, it just for one or two weeks only. (R3)

\section{Positive Emotions}

Positive emotions are all types of feelings that describe one's satisfaction with something. Two out of the nine teen smokers studied said smoking made them happy. They also confessed that smoking made them feel superior to non-smokers. This statement indicated that those teen smokers wanted to feel superior and at par with adults who smoke. Teen smokers also considered smoking to symbolise maturity. Besides that, another teen smoker found happiness from smoking based on what he experienced from this activity. They believed cigarettes have a pleasant taste capable of inducing excitement within themselves while smoking.

The behaviour of these smokers is coherent with a theory of emotions introduced by Socrates. The Good-Based Theories of Desire emphasises that an individual is compelled or motivated to do something due to favourable evaluation on their part (Kriegel, 2013; Lycan, 2012). In this context, researchers observed that smokers felt smoking had a positive effect on their emotions. Therefore, these teen smokers evaluated that smoking was a favourable behaviour and could benefit them. Thus, this appraisal has motivated them to smoke. The informant confessed that: 
INTERNATIONAL JOURNAL OF ACADEMIC RESEARCH IN PROGRESSIVE EDUCATION AND

DEVELOPMENT

Vol. 10, No. 2, 2021, E-ISSN: 2226-6348 @ 2021 HRMARS

"Sometimes i felt slightly happy. I don't know, may be because others did not smoke, but I did. I felt great and happy. Perhaps because i have been smoking for so long, and get used to it. Smoking makes me feel relief, feel good." (R7)

\section{Neutral Emotion}

Neutral emotion lies between the feelings of happy and sad. This feeling is associated with something that may not mean much to an individual. A total of five out of nine teen smokers described they had neutral emotions. Some smokers said they did not have any remorse at all because they enjoy smoking. Several of them even said they felt that way because they smoked every day. Furthermore, since other people also smoked, nothing became significant or made a difference to them. They proudly smoke in public places. One of the informants expressed:

"I do not feel regret. I don't think smoking is that bad. It is just a leisure activity. This is my view, I don't know how others' feel". (R8)

\section{parents' Negative Reactions towards the Habit of Smoking}

Negative reactions are indeed appropriate to be associated with young smokers. Results of this study showed that eight out of nine teen smokers received negative reactions from their parents, both verbally and physically. Some of them were reprimanded, scolded and even slapped by their fathers. Their parents punished, nagged and scolded them because they wanted their kids to quit smoking. Nonetheless, all of them still smoke. A few of them had quit smoking for a while before lighting up cigarettes again. Addiction to cigarettes and the surrounding factors have made it difficult for them to quit smoking; despite countless advice and warnings given by their parents. Over time, the parents of those teen smokers have to accept that their school-age children have become hardcore smokers.

Young smokers' neglect of their parents' advice and reprimands has made their parents permissive. The results of this study are parallel to another study conducted in Indonesia by Komasari and Helmi (2000). They discovered the permissive attitude of the parents was the reason why teen smokers continued to smoke. Those permissive parents did not prevent their children from smoking and acted as if they allowed their children to keep on doing so. This attitude could contribute to an increase in the number of young smokers. Theodorus (1994) said that families of smokers play more crucial roles in monitoring their children compared to families of non-smokers. Parents or guardians need to watch every move their children make to avoid them getting addicted to smoking. The reason being is smokers who start smoking at an early age will find it harder to quit.

A teen smoker who participated in this study said that his smoking activities were unknown to their parents. He has been smoking for four years, from the age of 13 . Smoking is easy to detect due to the strong smell of cigarette smoke that may linger in the smoking area, especially on the smoker's shirt. From a physical aspect, the unpleasant smell of cigarette smoke may reek on the shirt. Nevertheless, the teen smoker did not dare to be open with his parents about his smoking habit for fear of being scolded. The respondent stated: 
INTERNATIONAL JOURNAL OF ACADEMIC RESEARCH IN PROGRESSIVE EDUCATION AND DEVELOPMENT

Vol. 10, No. 2, 2021, E-ISSN: 2226-6348 @ 2021 HRMARS

"My parents did not know that I smoked. I never smoke in the house. I did not smoke while they are in. I am worry if they notice about it. So, they are still unaware about it until now." (R3)

This behaviour showed that the smoker was aware that his parents would be angry if they found out about the delinquent activity he was getting involved in. Therefore, the teen smoker chose to be more careful to avoid his unfavourable activities from being known to his parents. However, parents bear the responsibility to find out what their children are doing and with whom they associate. The teen smoker mentioned that his parents were always busy running their grocery store business. It showed that his parents did not spend much time with him and were neglectful. Being the only child in the family, the teen smoker spent most of his time with his friends.

The results of this study are consistent with research conducted on 367 lower secondary school students by Nurul Septiana, Syahrul, and Hermansyah (2016). They discovered that there was a significant relationship between parental control and smoking behaviour. The results indicated that students who were not under strict supervision by their parents were at a greater risk of getting addicted to cigarettes than those who do. Parents should not be either neglectful or overly restrain their children. Besides that, parents also need to spend more time with their children to show their care and affection. Unstable family structure, family conflict and lack of support are also significant factors contributing to smoking behaviour (Septiana, Syahrul \& Hermansyah, 2016).

Mahabee-Gittens et al. (2011) showed a relationship between family bonding and teen smokers during smoking initiation. Positive activities between parents and their children can prevent teenagers from starting to smoke. Furthermore, Loke and Mak (2013) also mentioned that family structure could affect childhood development. Therefore, it is important for parents not to neglect their children and to spend time with them. Mahmood (2001) pointed out that negative behaviours such as smoking are learned from the surrounding factors such as the parents, peers, local community and even mass media. However, parents certainly need to play a more vital role in curbing the habit of smoking.

\section{Negative Reactions from other People}

A negative response is unpleasant and symbolic disapproval of an act or conversation. Since smoking is viewed as a negative behaviour and unacceptable by society, especially when young people are involved, these teen smokers have to face ridicule and negative perceptions from people around them, including family members or other people they do not know. This situation occurs because smoking is perceived negatively by society and has always been a concern of many people.

The results of the study showed that all these teen smokers had gone through a phase where they were ridiculed and scolded by those around them over their smoking habits. Pictures of two of the nine teenagers in this study caught smoking in a restaurant in the morning hours 
once gone viral on Facebook. Besides that, one of them was scolded by an elderly man unknown to him while the rest had received warnings from their family members and neighbours. Salmi and Kivivuori (2006) mentioned several vital indicators of deviant behaviour (including smoking), namely lack of parental support, lack of control from teachers and the lack of intergenerational relationships. Lack of self-control has also been found to increase the risk of deviant behaviour. One of the informants shared his experience being embarassed in the facebook:

"When I was in form 2, somebody captured our photo and post it in fb. It went viral. Luckily, my face was not distinct in that photo. The statement he made in the fb was terrible: these students are wearing school uniform, but they were found smoking". (R9)

Since smoking is an unfavourable behaviour and falls under the category of delinquent activity, it is reasonable if many people express their disagreement over this behaviour. Nevertheless, the act of shaming someone over his or her bad behaviour is unacceptable. Although these teenagers committed such offence as smoking at the wrong location and age, it would have been better to reprimand them instead of insulting and embarrassing them.

\section{Awareness of the Risk of Smoking}

Based on the results of the study examined by the researchers, all those teen smokers were aware of the risk associated with smoking. The level of awareness displayed by these teenagers has shown that they all know the risk of smoking, at least about the diseases caused by that habit. Those teenagers became aware of the dangers of smoking from anti-smoking campaigns organised at schools, and when they found out about illnesses suffered by their friends due to smoking. Those teen smokers admitted they were unaware of the consequences or the risks caused by smoking during the initial phase of cigarette addiction. This indicated that they lacked knowledge about the risk of smoking at that time. The informant admitted:

"I did aware of the consequences of smoking. But, I still smoke until today. The awareness is there, but I cannot restrain myself. My buddy had problem with his lung, because he took vape, then cigaratte" (R9)

"Initially, I did not know, did not aware of the bad of smoking, that smoking is unhealthy. I observed that others were ok eventhough they smoked, nothing bad happen to them. But, later on I realized that smoking is detrimental, harmful." (R6)

This statement is supported by a study conducted by Rochayati and Hidayai (2015). They found that the level of knowledge is the most dominant factor in teenage smoking behaviour. A larger number of hardcore teen smokers are less knowledgeable about smoking compared to those who do. This finding suggests that the lack of knowledge about smoking behaviour has led teenagers to attempt smoking cigarettes and get themselves addicted. Awareness is also one of the factors involved in forming a new habit and necessary in obtaining sufficient knowledge about the risks of smoking through a continuous flow of information (Notoatmodjo, 2007: Amin, Manap \& Akhir, 2016; Hassan et al., 2014). Teenagers who has addicted to smoking must be guided so 
that they have the willingness and determination to quit smoking and other delinquencies (Zakaria et al., 2018).

\section{Conclusion}

In short, parents, society and teachers need to guide young people, particularly children and teenagers so that they will not go astray and take the wrong path. They are supposed to react negatively if young people go astray and take the responsibility to lead them. Teenagers are experiencing an identity crisis that can cause them, if left unattended, to make mistakes in choosing peer groups. Social acceptance is often the motivation for them to make decisions in life. Curiosity need to be controlled as they often lead teenagers to delinquent activities. They should channel those forces into positive behaviour that can develop their personalities and potentials. Teenagers should always be protected, monitored and mentored. Consequently, they can enter adulthood in a positive environment that supports healthy development.

The role of mentor, support group, and counselor are fundamental during adolecence years. They need to be informed about the harmful effects of smoking and other bad habits. Knowledge may lessen the desire to involve in deliquent activities and unhealthy lifestyle. Teens need to be acknowledged, cared, and loved by their significant person. If the bonding with the parents and teachers are good, the chances of getting involved in risky behavior will be less. They need to be prudently reminded about the cost and effect of their own behaviors. Smoking prevention programs should be planned carefully and conducted extensively at every schools. It should be made compulsory for all teens at school to join the programs.

\section{Ackhowledgement}

This research was supported by National University of Malaysia and the Ministry of Education Malaysia. The research code is FRGS/1/2020/SSO/UKM/02/29. Special thanks to the informants, experts and reseachers who have participated in this research.

\section{References}

Amin, A. S., Manap, J., \& Akhir, M. N. (2016). The Role of Family in the Lives of Disabled Malaysian Children. Akademika, 86 (1), 21-30.

Hassan, A., Yusoff, F., \& Alavi, K. (2014). Pengaruh Faktor Kesepaduan dan Kemahiran Keibubapaan Terhadap Kesejahteraan Psikologi Dalam Kalangan Ibu bapa dan Anak. Sains Humanika, 3 (1), 99-105.

Rochayati, A. S., \& Hidayai, E. (2015). Faktor-faktor yang mempengaruhi perilaku merokok remaja di sekolah menengah. Jurnal Keperawatan Soedirman (The Soedirman Journal of Nursing), 10 (1), 1-11.

Komasari, D., \& Helmi, A. F. (2000). Faktor-faktor penyebab perilaku merokok pada remaja. Jurnal Psikologi, 27 (1), 37-47.

Etrawati, F. (2014). Perilaku Merokok Pada Remaja: Kajian Faktor Sosio Psikologis. Jurnal IImu Kesehatan Masyarakat, 5 (2).

The Ministry of Health Malaysia (2015). Human resources for health country profile 2015 Malaysia. https://www.moh.gov.my/index.php/database_stores/store_view/26 
Kobus, K. (2003). Peers and Adolescent Smoking. Journal of Addiction, 9, 37- 55.

Kriegel, U. (2013). Justifying desires. Metaphilosophy, 44, 335-349.

Loke, A. Y., \& Mak, Y. (2013). Family process and peer influences on substance use by adolescents. International Journal of Environmental Research and Public Health, 10, 3868-3885.

Lycan, W. (2012). Desire considered as a propositional attitude, Philosophical Perspectives, 26, 201-215.

Mahabee-Gittens, E. M., Xiao, Y., Gordon, J. S., \& Khoury, J. C. (2013). The dynamic role of parental influences in preventing adolescent smoking initiation. Addictive behaviors, 38(4), 1905-1911.

Yahaya, M., Md Akhir, N., \& Sulaiman, M. N. (2019). Faktor Tingkah laku Merokok Dalam Kalangan Mahasiswa Universiti. Jurnal Personalia Pelajar, 21(2), 37-44.

Mahmood, N. M. (2001). Psikologi Pendidikan. Kuala Lumpur: Fajar Bakti Sdn. Bhd.

Gillmore, M. R., \& Wells, E. A. (2002). Children's beliefs about smoking. Nicotine \& Tobacco Research.

Notoatmodjo, S. (2007). Promosi kesehatan dan ilmu perilaku, Jakarta: Rineka Cipta.

Septiana, N. I. M., Syahrul, S. P. S., \& Hermansyah, S. K. M. (2016). Faktor Keluarga Yang Mempengaruhi Perilaku Merokok Pada Siswa Sekolah Menengah Pertama, Jurnal IImu Keperawatan, 4 (1), 1-14.

Salmi, V., \& Kivivuori, J. (2006). The association between social capital and juvenile crime: The role of individual and structural factors. European Journal of Criminology, 3 (2), 123-148.

Zakaria, S. M., Jaafar, J. R., Sarnon, N., Selamat, M. N., \& Tambi, N. (2018). Impak Terapi Kerja dalam Membantu Proses Kepulihan Klien CCRC. Akademika, 88 (2), 71-80.

Tobi, M. S. U. (2017). Kajian Kualitatif dan Analisis Temu bual. Kuala Lumpur, Malaysia: Aras Publisher.

Hussin, S., Chin, L. C., Hussin, M. F., \& Abd Rashid, A. R. (2004). Merokok Di Kalangan Remaja Malaysia. Shah Alam. Karisma Publications Sdn. Bhd.

Theodorus. (1994). Ciri Perokok di kalangan Mahasiswa/i universitas Sriwijaya, Jurnal JEN, 3, $19-24$.

Tirtosastro, S., \& Murdiyati, A. S. (2010). Kandungan Kimia Tembakau dan Rokok. Buletin Tanaman Tembakau, Serat \& Minyak Industri, 2 (1). 